\title{
HAK DAN KEWAJIBAN SEBAGAI DASAR NILAI INTRINSIK WARGA NEGARA DALAM MEMBENTUK MASYARAKAT SIPIL
}

Fahdian Rahmandani ${ }^{1}$, Samsuri ${ }^{2}$,

${ }^{12}$ Universitas Negeri Yogyakarta, Yogyakarta

* CORRESPONDENCE: $₫$ fahdianrahmandani.2017@ student.uny.ac.id

\begin{abstract}
Rights and obligations are one of the important elements that need to be cared for by the state. In the context of citizenship, rights and obligations become intrinsically basic values of citizens in building a civil society. Almost everyone has understood between rights and obligations as citizens, but because everyone does various activities, their rights and obligations are often forgotten. In state life, sometimes the rights of citizens face each other's obligations. So the writing of this article aims to find out the mapping of citizenship rights and obligations broadly which can be the basis of an intrinsic study by citizens in shaping civil society. Writing this article uses the library study method. The results of this study are theoretical explanations about (1) Overview of citizenship. (2)The mapping between complex rights and obligations of citizens. (3) Citizenship Education as an instrument to strengthen the intrinsic value of citizens' rights and obligations. (4) Establishment of civil society. And (5)
\end{abstract} Discussion.

Abstrak
Hak dan kewajiban merupakan salah satu elemen penting yang perlu di
rawat oleh negara. Dalam konteks kewarganegaraan, hak dan kewajiban
menjadi nilai dasar secara intrinsik warga negara dalam membangun
sebuah masyarakat sipil. Hampir semua orang telah memahami antara hak
dan kewajiban sebagai warga negara, akan tetapi karena setiap orang
melakukan aktivitas yang beragam maka apa yang menjadi hak dan
kewajibannya seringkali terlupakan. Dalam kehidupan kenegaraan kadang
hak warga negara saling berhadapan dengan kewajibannya. Maka penulisan
artikel ini bertujuan untuk mengetahui pemetaan hak dan kewajiban
kewarganegaraan secara luas yang dapat menjadi dasar kajian secara
intrinsik oleh warga negara dalam membentuk masyarakat sipil. Penulisan
artikel ini menggunakan metode studi kepustakaan. Hasil penelitian ini
berupa penjelasan secara teoretis tentang (1) Sekilas tentang
kewarganegaraan. (2) Pemetaan antara hak dan kewajiban warga negara
secara kompleks. (3) Pendidikan Kewarganegaraan sebagai instrumen
penguatan nilai intrinsik hak dan kewajiban warga negara. (4)
Terbentuknya masyarakat sipil. Dan (5) Diskusi.

\section{A. Pendahuluan}

Pada era Revolusi Industri 4.0 ini, segala upaya telah ditempuh dalam rangka mewujudkan suatu masyarakat yang adil dan makmur. Agar proses dalam pembangunan pada era ini berjalan dengan baik, perlu dukungan dari seluruh lapisan masyarakat dan seluruh aparatur Pemerintah. Salah satunya yaitu dengan melindungi kepentingan individu dan negara melalui proteksi hak dan kewajiban warga negara agar dapat terlaksana.

Dalam batas tertentu hampir semua orang telah memahami antara hak dan kewajiban sebagai warga negara, akan tetapi karena setiap orang melakukan aktivitas yang beragam maka apa yang menjadi hak dan kewajibannya seringkali terlupakan. Dalam kehidupan kenegaraan kadang hak

\author{
Article Info \\ Article History \\ Received : 12-03-2019, \\ Revised : 30-06-2019, \\ Accepted : 30-06-2019,

\section{Keywords:} \\ Right and Obligation; \\ Citizenship; \\ Civil Society;
}

\section{Histori Artikel \\ Disetujui : 30-06 -2019,}

\author{
Kata Kunci \\ Hak dan Kewajiban; \\ Warga Negara; \\ PKn; \\ Masyarakat Sipil;
}


warga negara saling berhadapan dengan kewajibannya. Bahkan tidak jarang kewajiban warga negara lebih banyak dituntut sementara hak-hak warga negara kurang mendapatkan perhatian.

Secara history, baik antara hak dan kewajiban kewarganegaraan dalam kehidupan kenegaraan maupun hak dan kewarganegaraan dalam kehidupan pribadi tidak pernah dirumuskan secara sempurna karena ada banyak pengaruh salah satunya sifat negara yang sangat dinamis. Maksudnya bahwa organisasi negara mengalami perkembangan sejalan dengan perkembangan manusia. Hubungan hak dan kewajiban warga negara yang berjalan beriringan menjadi sebuah asasi yang akhirnya memiliki konsekuensi logis hidup dalam organisasi negara. Hak dan kewajiban merupakan salah satu elemen penting yang perlu di rawat oleh negara. Dalam konteks kewarganegaraan, hak dan kewajiban menjadi nilai dasar secara intrinsik warga negara dalam membangun sebuah masyarakat sipil.

Namun lebih penting jika Negara yang diwakili oleh pemerintah sebagai pelaksana hukum merekonstruksi pemahaman hak dan kewajiban warga negaranya melalui Pendidikan. Karena dari hasil survei yang dilakukan oleh People For The American Way tahun 1989 di Amerika yang dijelaskan oleh Gonzale, Riedel, Avery, dan Sullivan bahwa dari 1.006 remaja dan dewasa menemukan bahwa ketika responden ditanya tentang kewarganegaraan yang baik, mereka memusatkan perhatian pada hak individu dengan mengabaikan tugas-tugas sipil dan partisipasi sebagai warga negara. Meskipun para responden menghargai kebebasan yang melekat dalam demokrasi, mereka tidak melaporkan rasa simpati pada tugas atau kewajiban untuk menjalankan tanggung jawab kewarganegaraan. Dalam penelitian ini meski telah berlangsung sangat lampau. Namun dapat kita jadikan pembelajaran bahwa negara besar se-kaliber Amerika masih memiliki permasalahan atas kesadaran warga negaranya terhadap hak dan kewajiban. Jika dibandingkan dengan Negara Indonesia, tentunya menjadi persoalan yang sama-sama rumit. Dalam asumsi penulis Negara Indonesia memiliki masalah yang lebih kompleks dalam hal ini, sehingga dibutuhkan solusi dari berbagai lini. Salah satunya yaitu dengan memberikan pendidikan kewarganegaraan kepada seluruh warga negara sebagai penguatan nilai intrinsik hak dan kewajiban. ${ }^{1}$

Pendidikan kewarganegaraan atau civic education adalah suatu ilmu pengetahuan yang bersifat multi-disiplin karena di dalamnya terdapat berbagai cabang ilmu yang mendukung pendidikan kewarganegaraan seperti ilmu politik, demokrasi, karakter dan moral. Dan pendidikan kewarganegaraan sendiri pada dasarnya memiliki tujuan tertentu yaitu untuk mencerdaskan kehidupan bangsa. Seperti yang dikatakan oleh Sunarso dkk bahwa Pendidikan kewarganegaraan (civic education) merupakan salah satu bidang kajian yang mengemban misi nasional untuk mencerdaskan kehidupan bangsa Indonesia melalui koridor "value-based education".

Jauh sebelumnya Giroux juga merumuskan pengertian mengenai pendidikan kewarganegaraan bahwa dalam definisi klasik tentang pendidikan kewarganegaraan Yunani, model rasionalitas dapat dikenali yang secara eksplisit bersifat politis, normatif, dan visioner. Dalam model ini, pendidikan

${ }^{1}$ M. H. Gonzales et al., "Rights and Obligations in Civic Education: A Content Analysis of the National Standards for Civics and Government," Theory \& Reserch in Social Education 29, no. 1 (2001): 109-28, https://doi.org/1080/00933104.2001.10505931.

2 Sunarso, dkk, Pendidikan Kewarganegaraan: PKN Untuk Perguruan Tinggi (Yogyakarta: UNY Press, 2008). 
dipandang secara intrinsik bersifat politis, dirancang untuk mendidik warga negara untuk partisipasi cerdas dan aktif dalam masyarakat sipil. ${ }^{3}$

Deny Setiawan dalam tulisannya menyatakan bahwa pendidikan Kewarganegaraan dengan paradigma baru berorientasi pada terbentuknya masyarakat sipil (civil society) dengan memberdayakan warga negara dalam sistem pemerintahan yang demokratis. Oleh karena itu, mata pelajaran pendidikan kewarganegaraan pada sekolah dasar perlu dirancang dengan menjabarkan komponen civic knowledge, civic skills dan civic dispositions secara fungsional, sehingga peserta didik sebagai warga negara dapat berpartisipasi secara aktif baik dalam tataran kehidupan bermasyarakat, berbangsa dan bernegara, serta dalam era kehidupan global (desirable personal qualities). Untuk tercapainya tujuan tersebut, maka pembelajaran PKn berbasis karakter perlu diterapkan melalui pembelajaran aktif. ${ }^{4}$

Pada tulisan tersebut, menyampaikan mengenai pentingnya pendidikan kewarganegaraan pada siswa sekolah dasar. Selanjutnya lebih jelas bahwa PKn berbasis karakter perlu di terapkan melalui pembelajaran secara aktif. Dalam tulisan ini belum di singgung mengenai Hak dan Kewajiban Sebagai Dasar Nilai Intrinsik Warga Negara Muda dalam Membentuk Masyarakat Sipil.

Berdasarkan uraian diatas, penulis tertarik untuk membahas secara cermat masalah hak dan kewajiban kewarganegaraan yang perlu dipetakan secara komprehensif kemudian menuangkannya dalam sebuah karya tulis berjudul "Hak dan Kewajiban, Sebagai Nilai Dasar Intrinsik Warga Negara dalam Membentuk Masyarakat Sipil". Kajian yang akan dibahas meliputi: (1) Sekilas Kewarganegaraan, (2) Pemetaan Hak dan Kewajiban, (3) Pendidikan Kewarganegaraan sebagai Instrumen Penguatan Dasar Nilai Intrinsik Hak dan Kewajiban Warga Negara, (4) Terbentuknya Masyarakat Sipil. (5) Diskusi.

\section{B. Metode Penelitian}

Metode dalam penulisan artikel ini menggunakan studi kepustakaan dengan mengolah data yang berasal dari berbagai sumber literatur. Kajian utama dalam artikel tentang Hak dan Kewajiban Warga Negara sebagai literatur primer. Selanjutnya disambung berbagai literatur sekunder yang menjelaskan tentang Kewarganegaraan, Pendidikan Kewarganegaraan, dan Masyarakat Sipil. Setelah diolah, data kemudian dianalisis, dirangkum, dan digeneralisasikan dengan menggunakan kajian teori yang memiliki relevansi sehingga dapat dirangkai menjadi satu kesatuan yang utuh.

\section{Pembahasan}

\section{Sekilas tentang Kewarganegaraan}

Istilah kewarganegaraan (citizenship) sudah dikenal sejak masa Yunani Kuno. Pada saat itu istilah kewarganegaraan masih dalam tahap perkembangan yang sangat sederhana sebagai bentuk status warga negara dari sebuah warga negara kota (city state). Pada abad kedelapan SM negara kota disebut sebagai polis, merupakan tempat tinggal warga negara dengan wilayah dan jumlah penduduk terbatas. Untuk menjadi warga polis ada dua faktor penentu, yaitu komitmen terhadap kesejahteraan polis dan kapasitas dari kebiasaan orang Yunani untuk berfikir secara abstrak. ${ }^{5}$

\footnotetext{
${ }^{3}$ H. A. Giroux, "Critical Theory and Rationaloty in Citizenship Education," Curriculum Inquiry 10, no. 4 (1980): 329-66.

4 Deny Setiawan, "Pendidikan Kewarganegaraan Berbasis Karakter Melalui Penerapan Pendekatan Pembelajaran Aktif, Kreatif, Efektif, Dan Menyenangkan,” Jurnal Pendidikan Ilmu-Ilmu Sosial 6, no. 2 (2014): 61-72.

${ }^{5}$ M. Murdiono, Pendidikan Kewarganegaraan Global: Membangun Kompetensi Global Warga Negara Muda, Cetakan Kedua (Yogyakarta: UNY Press, 2018).
} 
Perihal kajian tentang konseptualisasi kewarganegaraan tidak lepas dari penjelasan Banks tentang kewarganegaraan yang diakui. Wujud dari kewarganegaraan yang diakui tersebut berupa status yang disetujui oleh publik dan diakui oleh negara. Negara memandang individu-individu dan kelompok-kelompok ini sebagai anggota yang sah, legal, dan dihargai pemerintahan dan memberi mereka kesempatan untuk berpartisipasi penuh dalam negara-bangsa. Pencapaian status kewarganegaraan yang diakui memberi individu dan kelompok hak dan kesempatan untuk berpartisipasi penuh dalam komunitas sipil negara-bangsa. ${ }^{6}$ Kewarganegaraan sebenarnya tidak dapat dilepaskan dari arus yang lebih luas dan proses dalam membentuk masyarakat. Oleh karena itu penting untuk mempertimbangkan kewarganegaraan sebagai status dan serangkaian hubungan dimana keanggotaan dibangun melalui batas fisik dan metaforis. ${ }^{7}$ Perihal kewarganegaraan, Negara Indonesia juga mengatur yang termuat dalam UU Nomor 12 Tahun 2006 Tentang Kewarganegaraan Republik Indonesia.

Kewarganegaraan menyangkut hubungan negara dan warga negara. Kewarganegaraan adalah keanggotaan individu yang pasif dan aktif di negara-bangsa dengan hak dan kewajiban universalitas tertentu pada tingkat kesetaraan yang ditentukan. Dalam kajian Janoski telah menjadi diskursus terhadap bentuk kewarganegaraan yang dapat diterapkan pada tingkat nasional maupun individu. Konsep kewarganegaraan ini dapat ditinjau dari empat penjelasan sebagai berikut: 1) Kewarganegaraan dimulai dengan menentukan keanggotaan di suatu negara; 2) Kewarganegaraan melibatkan hak dan kewajiban aktif dan pasif; 3) Hak kewarganegaraan adalah hak universal yang disahkan menjadi undang-undang dan diimplementasikan untuk semua warga negara, dan tidak informal, tidak disengaja, atau partikular; dan 4) Kewarganegaraan adalah pernyataan kesetaraan, dengan hak dan kewajiban yang seimbang dalam batas-batas tertentu.

Sebagai warga negara yang memiliki keanggotaan di suatu negara, warga negara yang transformatif akan mengambil tindakan untuk mengimplementasikan dan mempromosikan kebijakan, tindakan, dan perubahan yang konsisten dengan nilai-nilai seperti hak asasi manusia, keadilan sosial, dan kesetaraan. Tindakan yang diambil oleh warga negara yang transformatif mungkin melanggar hukum lokal, negara bagian, dan nasional yang ada. Contohnya adalah tindakan yang diambil oleh warga transformatif seperti Mahatma Gandhi, Martin Luther King, Jr., dan Rosa Parks yang melanggar hukum nasional tetapi membantu mengaktualisasikan nilai-nilai seperti hak asasi manusia dan keadilan sosial dan menghilangkan diskriminasi dan ras yang dilembagakan. ${ }^{8}$

Warga negara yang transformatif mengambil tindakan untuk mengaktualisasikan nilai-nilai dan prinsip-prinsip moral yang melampaui negara-bangsa dan batas-batas nasional. Warga negara transformatif menggambarkan tiga konsepsi warga negara yang baik: (a) bertanggung jawab secara pribadi, (b) partisipatif, dan (c) berorientasi keadilan. Mereka mendefinisikan warga negara partisipatif "sebagai individu yang secara aktif berpartisipasi dalam urusan sipil dan kehidupan sosial masyarakat di tingkat lokal, negara bagian, atau nasional". 9

Menjadi warga negara penting untuk terlibat mengambil langkah-langkah dalam membela hakhak warga negara lainnya yang telah menjadi kepentingan bersama. Karena warga negara adalah

${ }^{6}$ J. A Banks, "Failed Citizenship and Transformative Civic Education," Educational Researcher 46, no. 7 (2017): 366-77, https://doi.org/10.3102/0013189X17726741.

7 L. A. Staeheli, "Political Geography: Where's Citizenship?," Progress in Human Geography 35, no. 3 (2010): 393-400, https://doi.org/10.1177/0309132510370671.

${ }^{8}$ Banks, "Failed Citizenship and Transformative Civic Education."

${ }^{9}$ Banks. 
seseorang yang pergi untuk membantu sesama warga negara yang sedang jatuh merasakan kegagalan dengan turut campur tangan ketika ia mampu mencegah tindakan kriminal yang berlangsung/ telah terjadi. Menjadi warga negara juga terlibat dan berperan aktif dalam arena politik formal dan informal.

Warga negara memiliki hak dan berhak atas perlindungannya. Setiap warga negara diharapkan setia kepada negara-bangsanya. warga negara dalam negara-bangsa yang pluralis dan demokratis harus mendukung cita-cita negara-bangsa secara menyeluruh, seperti tentang keadilan dan kesetaraan, berkomitmen untuk memelihara dan melanggengkan cita-cita bangsanya, dan bersedia mengambil tindakan untuk membantu menutup kesenjangan antara cita-cita dan praktik (seperti diskriminasi ras, etnis, dan agama dan ketidaksetaraan ekonomi).

Individu dan kelompok yang diakui sebagai warga negara memiliki kesempatan untuk berpartisipasi penuh dalam pemerintahan. Lembaga negara perlu memungkinkan kelompok etnis, ras, linguistik, dan agama yang terpinggirkan dan terstruktur untuk memperoleh kewarganegaraan yang diakui dan partisipatif untuk menciptakan negara-bangsa yang demokratis dan inklusif, mengaktualisasikan keadilan sosial dan kesetaraan, dan membantu beragam kelompok dalam pemerintahan untuk mengembangkan pemikiran dan identitas dan keterikatan nasional yang reflektif. ${ }^{10}$

Tentang hak, kewajiban, dan kebajikan warga negara tidak terlepas dari konsep kewarganegaraan keadilan yang secara eksplisit dijelaskan oleh Mason. Pada pembahasan ini Mason mengenalkan sebuah istilah yakni "akun keadilan". Akun keadilan menyatakan bahwa semua hak, kewajiban, dan kebajikan kewarganegaraan pada akhirnya diturunkan dari pertimbangan keadilan. Hak-hak kewarganegaraan tertuang sebagai masalah keadilan, dan kewajiban kewarganegaraan dipahami sebagai sarana seseorang melepaskan tugas-tugas keadilan yang ia tanggung kepada sesama warga negaranya. ${ }^{11}$

Pada akhirnya dalam perspektif akun keadilan, bertindak sebagai warga negara berarti bertindak atas dasar kepedulian terhadap apa yang diperlukan oleh sesama warga negara. Warga negara yang hidup dibawah institusi atau negara-bangsa harus turut mengemban tugas khusus dalam mempertahankan dan mempromosikan prinsip non-diskriminasi dan prinsip keadilan, yang dianggap penting dalam membentuk struktur dasar masyarakat. ${ }^{12}$

\section{Pemetaan Hak dan Kewajiban}

Antara Hak dan kewajiban kewarganegaraan ada di tingkat individu, kelompok, atau masyarakat. Di tingkat masyarakat mereka mengacu pada pengembangan hak, dan kewajiban kewarganegaraan di negara. Pada tingkat makro, fokusnya adalah pada keberadaan antara hak dan kewajiban secara universal dalam masyarakat dengan tingkat kesetaraan yang ditentukan. Di tingkat kelompok, mereka memperhatikan hak dan kewajiban untuk membentuk dan bertindak, dan sebagai penjelasan kewarganegaraan. Mereka memasukkan ideologi dan tuntutan akan hak dan kewajiban yang dapat dibuat oleh berbagai kelas dan status kelompok. Pada tingkat mikro, definisi kewarganegaraan individu berfokus pada bagaimana setiap orang melihat hubungan hak dan kewajiban dalam kerangka keseimbangan. Ini melacak perkembangan "diri" dalam kaitannya

\footnotetext{
${ }^{10}$ Banks.

11 A. Mason, “Citizenship and Justice," Politics, Philosophy \& Economics 10, no. 3 (2011): 263-81, https://doi.org/10.1177/1470594X10386563.

${ }^{12}$ Mason.
} 
dengan negara sebagai bagian penting dari kewarganegaraan, terutama pengembangan sikap dan perilaku yang berorientasi pada diri sendiri atau masyarakat.

Mengacu pada hak-hak sipil sebagai "keadaan hukum keberadaan" dan hak-hak politik sebagai "kekuatan hukum melakukan", membantu untuk menjelaskan secara mendasar keempat hak berikut. Dalam istilah being "menjadi", seseorang berarti memiliki hak (secara pasif). Dan doing "melakukan" berarti seseorang memiliki keterikatan dalam menciptakan hak, merupakan proses aktif yang dijelaskan oleh kekuasaan. Dalam menyusun tipologi hak kewarganegaraan, hak dapat diklasifikasikan berdasarkan ruang publik dan privat. Hak-hak publik meliputi hak sipil dan politik, juga digunakan untuk membantu mengembangkan undang-undang publik. Sedang, hak privat melibatkan intervensi terhadap kesejahteraan individu baik di rumah maupun tempat kerja, atau membantu penciptaan hak pada ranah privat seperti organisasi dan pasar. Sehingga dalam jelajah Janoski hak kewarganegaraan dapat dibedakan menjadi empat untai yang meliputi, hak hukum, hak politik, hak sosial, dan hak partisipatif. ${ }^{13}$

Hak hukum terdiri dari lima elemen yang meliputi hak prosedural, hak ekspresif, kontrol tubuh, hak properti dan layanan, serta hak organisasi. Interpretasi hak prosedural meliputi akses ke pengadilan dan penasihat; hak kontrak; perlakuan yang sama dibawah hukum; hak orang asing untuk berimigrasi dan warga negara untuk berimigrasi. Hak ekspresif berupa kebebasan berbicara; kebebasan beragama; memilih teman dan rekan; serta memiliki hak kebebasan. Hak kontrol tubuh yaitu berupa bebas dari penyerangan dan lingkungan yang tidak aman; dan kontrol medis serta seksual atas tubuh. Hak properti dan layanan meliputi pegang dan membuang properti dan layanan; memilih tempat tinggal; dan memilih pekerjaan. Hak organisasi meliputi pengorganisasian karyawan; pengorganisasian perusahaan; dan pengorganisasian partai politik.

Hak politik terdiri dari empat elemen yang meliputi hak pribadi, hak organisasi, hak naturalisasi, dan hak oposisi. Hak pribadi dapat di interpretasi melalui pemberian hak orang miskin, kelompok gender, kelompok etnis/ras, kategori umur dan imigran; hak untuk menjalankan dan memegang jabatan; dan hak untuk membentuk dan bergabung dengan partai politik. Hak organisasi meliputi lobi politik; penggalangan dana politik; konsultasi legislatif dan administratif; dan perundingan politik. Hak naturalisasi berupa hak untuk naturalisasi atas izin tinggal; hak atas informasi tentang proses naturalisasi; dan hak-hak pengungsi. Hak oposisi terdiri dari hak minoritas atas perlakuan yang sama dan adil; informasi politik dan hak penyelidikan; dan gerakan sosial serta hak melakukan protes.

Hak sosial terdiri dari empat elemen yang meliputi hak pengaktifan dan pencegahan, hak peluang, hak distribusi, dan hak kompensasi. Hak pengaktifan dan pencegahan berupa layanan kesehatan; tunjangan keluarga; konseling pribadi dan keluarga; dan rehabilitasi fisik. Hak peluang yang berupa pendidikan pra-sekolah dasar; pendidikan dasar dan menengah; pendidikan tinggi; pendidikan kejuruan; dan bantuan pendidikan untuk kelompok-kelompok khusus. Hak distribusi berupa pensiunan hari tua; bantuan publik; dan kompensasi pengangguran. Hak kompensasi berupa asuransi cedera kerja; pensiunan cedera perang; penyetaraan perang; dan kompensasi pelanggaran hak.

Hak partisipasi terdiri dari tiga elemen yang meliputi hak intervensi pasar tenaga kerja, hak perusahaan dan birokrasi, dan hak kontrol modal. Hak intervensi pasar modal berupa program

${ }^{13}$ T. Janoski, Citizenship and Civil Society: A Framework of Right and Obligation in Liberal, Traditional, and Social Democratic Regimes (Cambridge: Cambridge University Press, 1998). 
informasi pasar kerja; program penempatan kerja; dan layanan penciptaan lapangan kerja. Hak perusahaan dan birokrasi meliputi hak keamanan pekerjaan, dewan pekerja atau hak prosedur pengaduan; partisipasi klien dalam birokrasi atau administrasi mandiri; tindakan afirmatif dan nilai yang sebanding; dan hak tawar kolektif. Hak kontrol modal berupa hak kodeterminasi; penghasil upah dan dana investasi serikat; undang-undang pelarian modal; undang-undang anti-kepercayaan; dan investasi regional dan program pemetaan.

Pertama, dalam hak hukum untuk individu sebagian besar diproyeksikan tentang kebebasan. Pertama-tama ada hak prosedural untuk mengakses sistem pengadilan dan menerima perlakuan yang adil. Selanjutnya ada tiga jenis hak substantif yang berbeda. Dilanjutkan pada bagian kedua, hak ekspresif yang berupa pada kebebasan berbicara, beragama, dan kehidupan yang privasi. Bagian ketiga, Hak kontrol tubuh meliputi hak inheren seseorang terhadap integritas tubuh dan termasuk kebebasan praktik seksual dan kontrol atas intervensi medis ke dalam proses tubuh internal, seperti hak untuk melakukan aborsi dan hak mendapat perlindungan dari serangan orang lain ada dalam kategori ini. Bagian keempat hak properti dan layanan yang mencakup hak atas properti dan pilihan tentang lokasi perumahan, pekerjaan, dan mobilitas sosial. Bagian terakhir pada hak hukum yaitu hak organisasi untuk membentuk serikat pekerja, bisnis, dan partai politik.

Kedua, Hak politik termasuk hak warga negara untuk memilih dan berpartisipasi dalam proses politik. Dalam hak politik ini memberikan kesempatan pada setiap individu untuk menentukan pilihan atas kelompok gender, kelompok etnis / ras, kategori umur dan sebagai imigran. Mereka juga melibatkan prosedur untuk memilih perwakilan politik, menciptakan undang-undang baru, dan mencalonkan diri untuk dan memegang jabatan politik. Bagian kedua, hak politik untuk organisasi mencakup penggalangan dana kampanye, konsultasi dengan legislator mengenai proposal, mencalonkan kandidat politik, dan me-lobi untuk kebijakan tertentu. Bagian ketiga, hak politik untuk para warga naturalisasi yaitu hak mendapatkan perlindungan bagi orang asing dan pengungsi ke dalam proses naturalisasi yang wajar. Akhirnya, hak politik untuk beroposisi yaitu dengan melindungi minoritas, untuk memprotes, untuk menunjukkan, dan memungkinkan mereka mendapatkan informasi dari pemerintah dan melakukan penyelidikan politik.

Ketiga, hak sosial berupa intervensi publik ke ranah privat demi mendukung klaim warga terhadap penghidupan ekonomi dan eksistensi sosial. Adanya hak sosial juga turut mengubah distribusi sumber daya pasar swasta. Hak sosial sebagian besar individu terdiri dari empat bagian. Bagian pertama yaitu tentang hak-hak yang memungkinkan menyangkut layanan kesehatan dan keluarga untuk menjamin fungsi dasar warga di masyarakat. Bagian kedua hak atas peluang yang memungkinkan warga mendapatkan keterampilan yang diperlukan untuk kerja dan partisipasi dalam budaya melalui bantuan pendidikan dasar, menengah, dan tinggi. Bagian ketiga, berupa hak distribusi dengan memberikan pembayaran transfer untuk memastikan bahwa pekerja, pensiunan, orang cacat, anak-anak, orang tua tunggal, dan semua warga lainnya menerima penghidupan ekonomi. Akhirnya, bagian hak kompensasi, memberikan pembayaran kompensasi kepada veteran yang cacat, pekerja yang terluka, dan warga yang hak-haknya telah diringkas dengan cara tertentu. Dengan demikian, hak-hak sosial berkisar dari hak distribusi dengan pembayaran uang hingga hakhak yang memungkinkan dan kesempatan dengan banyak layanan pribadi.

Keempat, hak partisipasi yang melibatkan penciptaan hak negara di ranah privat, baik di pasar atau organisasi publik. Sama seperti hak politik adalah kekuatan tindakan publik, hak partisipasi adalah kekuatan tindakan swasta yang dijamin negara. Mereka mengacu pada hak individu dan kelompok untuk berpartisipasi dalam pengambilan keputusan privat melalui beberapa ukuran 
kontrol atas pasar, organisasi, dan modal. Hak intervensi pasar tenaga kerja melibatkan partisipasi publik dengan menjamin pekerjaan bagi warga negara dalam penempatan kerja, pelatihan ulang, dan program penciptaan pekerjaan. Hak partisipasi organisasi dapat berkisar dari hak individu untuk berpartisipasi dalam keputusan di tempat kerja dalam penentuan bersama dan dewan pekerja, sehingga masyarakat memiliki hak untuk turut berpartisipasi dalam perawatan kesehatan dan keputusan dampak lingkungan. Hak partisipasi bahkan turut menjamin hak politik dalam konteks beragama, misalnya dengan mengamanatkan dewan agama menjamin hak partisipasi perempuan untuk menjadi imam di Gereja Katolik. Akhirnya pada hak partisipasi modal melibatkan pekerja dan partisipasi publik dalam keputusan tentang investasi di perusahaan dan arus modal di dalam dan di luar negeri.

Pada penjelasan yang menyajikan kisaran tentang hak bertujuan untuk mengukur di mana negara-negara dapat berdiri di atas hak kewarganegaraan masing-masing. Hak hukum adalah kebebasan dan lebih terbuka. Warga negara memiliki kebebasan untuk memilih agamanya dan mengekspresikan pendapatnya tentang suatu masalah. Namun kebebasan menuntut toleransi terhadap pilihan masing-masing dan perlindungan negara atas pilihan-pilihan itu. Hak politik dan partisipasi adalah kekuatan yang mewakili hak kooperatif di mana orang dan kelompok harus bekerja sama untuk mengaktifkan hak-hak ini secara prosedural. Hak-hak sosial adalah klaim yang bergantung langsung pada orang lain untuk membayar tunjangan pengangguran dan bantuan publik sehingga warga negara lain dapat menerima penghidupan.

Selanjutnya tentang kewajiban kewarganegaraan yang rinciannya tidak terlepas dari rumusan hak-hak kewarganegaraan. Menjaga kewajiban kepada orang lain dan diri sendiri tidak terlepas bagaimana seseorang juga menghormati hak orang lain. Karena tidak ada hak yang mungkin ada tanpa kewajiban dalam membantu hak menjadi ada. Secara eksplisit keseimbangan antara hak dapat disimpulkan bahwa keseimbangan hak kewarganegaraan dan kewajiban warga negara diperlukan. Sama halnya dengan hak kewarganegaraan, bahwa kewajiban warga negara dapat dibagi menjadi empat dimensi yang meliputi kewajiban hukum, kewajiban politik, kewajiban, sosial, dan kewajiban partisipasi. ${ }^{14}$

Kewajiban hukum terdiri dari tiga elemen meliputi kewajiban interpersonal, tugas organisasi, dan kewajiban penegakan dan implementasi. Kewajiban interpersonal berupa menghormati hak orang lain atas kebebasan, seperti kebebasan berbicara/berpendapat, memeluk agama, dan memiliki properti; dan menghormati hukum/perjanjian kontrak, asosiasi, dan perlakuan yang sama/setara. Tugas organisasi berupa tugas untuk mempromosikan kesejahteraan umum, menghormati hak-hak individu, dan menghormati hak hukum yang dibuat oleh pemerintah. Penegakan dan pelaksanaan dalam kewajiban hukum berupa menyediakan sumber daya untuk sistem hukum, membantu dalam memastikan ketenangan domestik, dan menghormati dan bekerja sama dengan polisi dalam memastikan hak-hak hukum.

Kewajiban politik memiliki elemen sama dengan dimensi kewajiban hukum yang terdiri dari kewajiban interpersonal, tugas organisasi, dan kewajiban penegakan dan pelaksanaan. Kewajiban interpersonal dalam kewajiban politik berupa memilih dan berpartisipasi dalam politik, mendapat informasi dan menjalankan waralaba dengan bijak, menghormati demokrasi dan tidak membuat tuntutan yang tidak masuk akal. Tugas organisasi berupa bekerja sama dengan kelompok lain dalam operasi politik, dan mentaati hukum dan peraturan politik. Penegakan dan pelaksanaan dalam

\footnotetext{
${ }^{14}$ Janoski.
} 
kewajiban politik berupa menyediakan sumber daya untuk melindungi dan mengoperasikan sistem demokrasi, melindungi negara dari ancaman melalui layanan aktif di militer (wajib militer), dan memprotes serta menggulingkan pemerintah yang melanggar hak.

Kewajiban sosial terdiri dari empat elemen meliputi mengaktifkan dan tugas pencegahan, kewajiban peluang, kewajiban keuangan (ekonomi), dan penegakan dan pelaksanaan. Mengaktifkan dan tugas pencegahan berupa kewajiban untuk mengikuti perawatan kesehatan, memelihara keluarga yang penuh kasih, dan menjaga lingkungan yang aman dan bersih. Kewajiban peluang berupa mengejar pendidikan dengan kemampuan terbaiknya, mengejar karir untuk kepentingan masyarakat, dan toleransi dalam keragaman sosial. Kewajiban keuangan (ekonomi) berupa kewajiban bagi pengangguran atau penerima bantuan publik harus mencari pekerjaan, dan menghormati hak-hak sosial orang lain dan perlunya pembayaran transfer. Penegakan dan pelaksanaan dalam kewajiban sosial berupa menyediakan sumber daya untuk hak-hak sosial, dan membantu yang kurang mampu (beruntung) oleh volunter pemerintah dan layanan asosiasi.

Kewajiban partisipasi terdiri dari empat elemen meliputi kewajiban pasar tenaga kerja, kewajiban perusahaan/birokrasi, kewajiban partisipasi modal, dan penegakan dan pelaksanaan. Kewajiban pasar tenaga kerja berupa tugas menerima layanan secara aktif untuk memburu pekerjaan, tugas pengusaha untuk bekerja sama dengan pemerintah dan serikat pekerja untuk menyediakan program. Kewajiban perusahaan/birokrasi berupa memastikan kesetaraan dan produktivitas dalam organisasi (perusahaan), menjaga informasi kompetitif perusahaan, dan menghormati semua kelompok dalam proses partisipatif. Kewajiban partisipasi modal berupa melindungi dan mempromosikan ekonomi, dan menyediakan dana modal melalui tabungan. Dan penegakan dan pelaksanaan dalam kewajiban partisipasi ini berupa menyediakan sumber daya untuk program dan berinvestasi dalam industri nasional.

Seperti halnya hak, Janoski menjelaskan jika kewajiban dapat bertentangan dengan kewajiban lain dan dengan hak kewarganegaraan. Misalnya, kewajiban untuk menghormati kebebasan (yaitu, kebebasan pribadi) dapat bertentangan dengan kewajiban politik untuk melindungi masyarakat dari ancaman asing (yaitu, wajib militer); atau menghormati undang-undang dan kebebasan orang lain (yaitu, toleransi) dapat bertentangan dengan kewajiban untuk menggulingkan pemerintah yang secara sistematis melanggar prinsip-prinsip demokratis (yaitu, kewajiban untuk melindungi demokrasi). Masyarakat dapat dengan jelas menegosiasikan berbagai kompromi antara hak dan kewajiban dalam sistem kewarganegaraan secara keseluruhan. ${ }^{15}$

\section{PKn sebagai Instrumen Penguatan Nilai Intrinsik Hak dan Kewajiban Warga Negara}

Periode perubahan yang belum pernah terjadi sebelumnya dan tampaknya tanpa henti ini telah berhasil menggeser dan menegakkan batas-batas kewarganegaraan yang stabil dan tradisional di banyak masyarakat. Hubungan yang kompleks antara kewarganegaraan dan pendidikan untuk kewarganegaraan menyebabkan re-definisi berkala yang coba dijelaskan oleh Kerr bahwa Pendidikan Kewarganegaraan merupakan hasil produk perdebatan mengenai perubahan sifat kewarganegaraan dalam masyarakat modern dan peran pendidikan dalam masyarakat yang berkonsentrasi pada empat aspek yaitu hak dan tanggung jawab, akses, kepemilikan, dan identitas lainnya. ${ }^{16}$

${ }^{16}$ D. Kerr, "Citizenship Education in England: The Making of a New Subject," Online Journal for Social Science Education 2 (2003): 1-10. 
Pendidikan Kewarganegaraan "Civic Education" tidak hanya sebuah mata pelajaran di persekolahan, tetapi lebih dari pada itu bahwa Pendidikan Kewarganegaraan "Citizenship Education" merupakan suatu usaha sadar dalam menyiapkan dan membekali warga negara sebagai generasi bangsa yang kelak dapat berperan aktif dalam masyarakat (community civics). Jika merujuk pada pendapat Kerr bahwa Pendidikan Kewarganegaraan memiliki tiga bentuk yang dapat diberikan kepada warga negara. Bentuk pertama adalah Pendidikan tentang Kewarganegaraan (education about citizenship); kedua, Pendidikan melalui Kewarganegaraan (education through citizenship); dan ketiga Pendidikan untuk Kewarganegaraan (education for citizenship). Singkatnya Pendidikan Kewarganegaraan mencakup seperangkat alat yang memungkinkan akan membawa warga negara berpartisipasi secara aktif dan masuk akal dalam peran dan tanggung jawabnya sebagai warga negara. Dan Pendidikan Kewarganegaraan tidak hanya sebatas pendidikan yang ada dalam konteks persekolahan saja, lebih daripada itu masyarakat diluar juga penting untuk mendapat Pendidikan Kewarganegaraan. ${ }^{17}$

Pendidikan Kewarganegaraan sebagai disiplin khusus di sekolah, diharapkan mampu membawa siswa untuk belajar tentang masyarakat mereka sendiri. Artinya bagaimana mereka menjadi individu yang terkait dengan masyarakat, atau bagaimana mereka mampu memaknai menjadi seorang warga negara dengan memahami hak dan tanggung jawabnya. Pendidikan Kewarganegaraan di sini bertujuan untuk mengembangkan kapasitas siswa agar berguna dalam masyarakat modern. Seperti kapasitas untuk membentuk dan mengekspresikan pendapat sendiri, untuk mengevaluasi kontribusi dan kinerja tokoh-tokoh publik seperti politisi dan pejabat dan sampai pada kemampuan memberikan kesimpulan rasional tentang apa yang benar dan salah. ${ }^{18}$

Pendidikan yang efektif untuk kewarganegaraan terdiri dari untaian yang saling terkait namun berbeda. Pertama, tanggung jawab sosial dan moral, anak-anak belajar dari rasa percaya diri yang sangat awal dan perilaku yang bertanggung jawab secara sosial dan moral baik di dalam maupun di luar kelas, baik terhadap mereka yang berwenang dan terhadap satu sama lain. Kedua, keterlibatan masyarakat, belajar tentang dan menjadi sangat membantu terlibat dalam kehidupan dan keprihatinan komunitas mereka, termasuk belajar melalui keterlibatan masyarakat dan layanan kepada masyarakat. Ketiga, melek politik (literacy politic), siswa belajar tentang dan bagaimana membuat diri mereka efektif dalam kehidupan publik melalui pengetahuan, keterampilan dan nilainilai. Kehidupan publik menjadi ruang yang digunakan untuk mencakup pengetahuan realistis dan persiapan atas resolusi konflik dan pengambilan keputusan, baik yang melibatkan masalah di tingkat lokal, nasional, atau global. ${ }^{19}$

Kasus dalam mendefinisikan kembali kewarganegaraan tentunya akan berpengaruh pada pendidikan kewarganegaraan. Karena membentuk kembali kewarganegaraan berarti merumuskan kembali pendidikan kewarganegaraan. Hal semacam ini tentunya akan memicu perdebatan kembali pada peran yang harus dimainkan kembali oleh sekolah, kurikulum, dan guru.

Studi Pendidikan Kewarganegaraan yang lebih sempit sedang dilengkapi oleh Pendidikan Kewarganegaraan yang lebih luas, berkaitan dengan berbagai cara warga negara berinteraksi

\section{${ }^{17}$ Kerr.}

${ }^{18}$ G. H. Frimannsson, “Civic Education and the Good," Studies in Philosophy and Education 20, no. 4 (2001): 303-15, https://doi.org/10. 1023/A:1011834707490.

19 j. Tonge, A. Mycock, and B. Jeffery, "Does Citizenship Education Make Young People Better-Engaged Citizens?," Political Studies 60, no. 3 (2012): 578-602, https://doi.org/10. 1111/j. 1467-9248.2011.00931.x. 
dengan membentuk komunitas mereka. ${ }^{20}$ Pendidikan Kewarganegaraan yang juga disebut Civics didefinisikan sebagai sebuah studi tentang pemerintahan dan kewarganegaraan yang terkait dengan kewajiban, hak, dan hak-hak istimewa warga negara. Sehingga dapat disimpulkan bahwa PKn merupakan studi yang memfokuskan pada pembentukan warga negara yang memahami dan mampu melaksanakan hak dan kewajibannya sesuai dengan konstitusi yang mengaturnya. ${ }^{21}$

\section{Terbentuknya Masyarakat Sipil}

Secara history kemunculan masyarakat sipil pertama kali dikenal dari proses sejarah masyarakat barat. Cicero adalah akar menggunakan istilah tersebut dalam filsafat politiknya (10643 SM), dan dilanjutkan oleh Aristoteles (384-322 SM). Dalam kajian Aristoteles istilah masyarakat sipil tidak menggunakan istilah civil society, melainkan menggunakan istilah koinie politike, yaitu sebuah komunitas politik sebagai tempat warga untuk dapat terlibat dalam sebuah pengambilan keputusan. $^{22}$

Antara Negara dan masyarakat sipil dalam bukunya Hikam dijelaskan sebagai dua bentuk entitas berbeda, pertama sejalan dengan proses pembentukan sosial dan perubahan arus atau struktur politik di Eropa diakibatkan oleh zaman enlighment, dan kedua tergesernya rezim absolut oleh modernisasi. ${ }^{23}$ Sedang model yang dikemukakan Gramsci dan Tocqueville banyak memberikan inspirasi terhadap pergerakan masyarakat sipil, terutama beberapa negara Eropa yang menular sampai dengan negara di Asia bahkan seluruh dunia. Karena gerakan masyarakat sipil menjadi gambaran perjuangan untuk membangun harga diri individu sebagai warga negara. Gagasan masyarakat sipil merupakan landasan ideologis untuk membebaskan diri dari cengkraman negara secara sistemis dalam penguatan daya kreasi dan kemandirian. ${ }^{24}$

Namun cukup disayangkan pada era modern sekarang ini Negara ikut campur tangan terhadap rekonstruksi masyarakat sipil. Dalam ambisinya, negara tidak hanya melakukan kooptasi atau mengintegrasikan, tetapi juga menciptakan kembali masyarakat sipil. Melalui pencarian metode baru pemerintah ingin menemukan kembali atau merevitalisasi kondisi sosial, dengan melakukan rekonstruksi dalam skala besar terhadap masyarakat sipil. Salah satu strategi yang terlibat dalam proses ini adalah penggunaan modal sosial. Organisasi sektor ketiga atau masyarakat sipil ditunjuk sebagai posisi dan fungsi dari pemerintah. Alasannya bahwa pemerintah ingin warga negara untuk berpartisipasi dalam kehidupan bernegara. Sehingga muncullah image bahwa negara mengambil alih dalam memproduksi organisasi semacam masyarakat sipil sebagai sarana mengimplementasikan kebijakan publik. ${ }^{25}$

Masyarakat sipil seharusnya menjadi representasi demokrasi dengan menghendaki institusiinstitusi yang berada pada sektor publik, swasta, maupun sukarela dengan membentuk forum-forum

${ }^{20}$ G. Jover, Citizenship Education In and Out of School. In School Curriculum and Civic Education for Building Democratic Citizens by Murray Print and Dirk Lange (Rotterdam: Sense Publishers, 2012).

${ }^{21}$ A. Ubaedillah and A. Rozak, Pendidikan Kewargaan (Civic Education) Demokrasi, Hak Asasi Manusia Dan Masyarakat Madani (Jakarta: ICCE UIN Syarif Hidayatullah, 2008).

${ }^{22}$ J.L. Cohen and A. Arato, Civil Society and Political Theory (Cambridge: The MIT Press, 1992).

${ }^{23}$ M. A.S Hikam, Demokrasi Dan Civil Society, II (Jakarta: LP3ES, 1999).

${ }^{24}$ A. S. Karni, Civil Society \& Ummah (Jakarta: Logos, 1999).

25 W. T. Trommel Brandsen and B. verschuere, "The State and The Reconstruction of Civil Society," International Review of Administrative Sciences 83, no. 4 (2017): 676-93, https://doi.org/10. 1177/0020852315592467. 
asosiasi yang jelas arahnya dan dapat dikontrol. Forum atau asosiasi semacam itu harus bersifat terbuka, inklusif, dan menjadi mimbar masyarakat untuk mengekspresikan aspirasinya. ${ }^{26}$

Kajian masyarakat sipil memang belum menjadi ide sentral dalam ilmu sosial seperti halnya kewarganegaraan. Definisi masyarakat sipil dapat ditinjau dari definisi normatif yang telah dijelaskan dalam bukunya Janoski bahwa masyarakat sipil sebagai "mediasi lembaga" yaitu antara warga negara dan negara. Masyarakat sipil merupakan wacana publik yang dinamis dan responsif yang memiliki hubungan antara empat bidang, meliputi ruang privat, ruang pasar, ruang publik, dan ruang negara. ${ }^{27}$

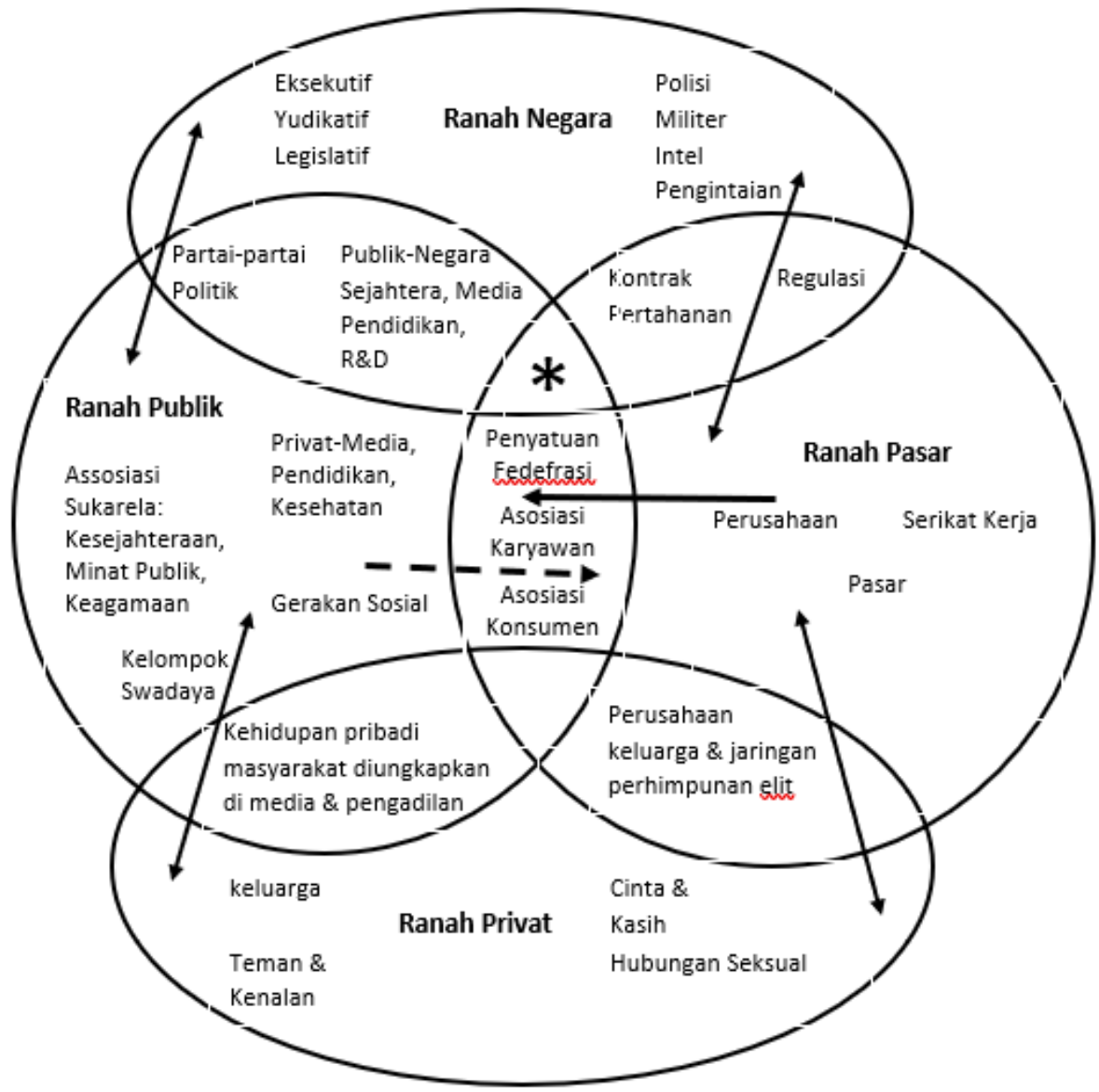

Gambar 1 Diagram konseptual dari ruang publik dan pribadi yang menempatkan masyarakat sipil

Pada diagram diatas telah diuraikan oleh Janoski, ${ }^{28}$ pada bidang pertama ruang negara dan swasta tidak memiliki kerumitan seperti ruang lainnya yakni publik dan pasar. Ruang negara melibatkan organisasi negara (eksekutif sebagai pelaksana-hukum, legislatif sebagai pembuat undang-undang, dan yudikatif pengevaluasi konstitusi). Bidang kedua, yaitu ruang privat memiliki banyak komponen di dalamnya seperti kehidupan keluarga, jaringan teman dan kenalan, dan disposisi properti pribadi. Keberadaan ruang privat bergantung pada hak privasi, tetapi di zaman modern, negara, pasar, dan ruang publik telah banyak menginvasi ruang privat warga negara.

${ }^{26}$ A. Budiman, State and Civil Society: The Publications Officer, Centre of Southeast Asian Studies (Victoria: Monash University, 1990).

${ }^{27}$ Janoski, Citizenship and Civil Society: A Framework of Right and Obligation in Liberal, Traditional, and Social Democratic Regimes.

${ }^{28}$ Janoski. 
Bidang ketiga, ruang pasar yang terdiri dari organisasi swasta dan beberapa organisasi publik yang terlibat dalam penciptaan instrumental pendapatan dan kekayaan melalui produksi barang dan jasa. Bagian terakhir yaitu ruang publik merupakan aspek yang paling penting tetapi sulit ntuk diklasifikasi karena melibatkan berbagai organisasi. Setidaknya ada lima jenis asosiasi sukarela yang beroperasi di ruang publik: partai politik, kelompok kepentingan, asosiasi kesejahteraan, gerakan sosial, dan badan keagamaan.

Masyarakat sipil dalam pengertian ini adalah sebuah arena di mana manusia modern tidak hanya secara sah memuaskan kepentingannya sendiri dan mengembangkan individualitasnya, tetapi juga mempelajari nilai aksi kelompok, solidaritas sosial, dan ketergantungan kesejahteraannya pada orang lain, yang mendidiknya untuk kewarganegaraan dan mempersiapkannya untuk berpartisipasi dalam arena politik negara. ${ }^{29}$

Konsep modern masyarakat sipil perlu memiliki dimensi moral, normatif yang jelas. Nilai-nilai moral dalam hal ini dapat berupa kejujuran, keadilan, keikhlasan, dan tanggung jawab. Dalam istilah klasik tentang optimisme melibatkan daya tarik moral untuk hidup lebih beradab. Berkaitan erat dengan konsep peradaban dalam membentuk masyarakat yang baik. ${ }^{30}$

Kemudian untuk mempertegas pandangan tentang masyarakat sipil, Diamound menegaskan lima ciri masyarakat sipil, diantaranya: 1) Tujuan masyarakat sipil untuk kepentingan publik; 2) Masyarakat sipil tidak memiliki tujuan lain seperti merebut kekuasaan, mencari posisi penting, atau mengendalikan politik selain sebagai partner berhubungan dengan negara; 3) Masyarakat sipil bersifat pluralisme dan keberagaman; 4) Dalam masyarakat sipil tidak berusaha menampilkan seluruh kepentingan pribadi atau komunitas; dan 5) Masyarakat sipil harus sebagai organisasi atau lembaga yang mampu meningkatkan demokrasi. ${ }^{31}$

Akhir dalam penjelasan subtansi ini, Masyarakat sipil terdiri dari kelompok dan organisasi, baik formal maupun informal, yang bertindak independen terhadap negara dan pasar untuk mempromosikan beragam kepentingan dalam masyarakat. Ini mewakili organisasi swadaya, mandiri dan mandiri yang memungkinkan warga negara untuk bertindak secara kolektif di ruang publik untuk mengekspresikan kepentingan mereka. Ini terkait dengan seperangkat institusi yang memediasi antara individu dan negara. Karena itu, ia bertindak pada tingkat makroskopis. Ini mencakup keseluruhan organisasi yang oleh para ilmuwan politik secara tradisional dilabeli oleh kelompok-kelompok kepentingan - tidak hanya advokasi organisasi non-pemerintah (LSM) tetapi juga serikat pekerja, asosiasi profesional (seperti dokter dan pengacara), kamar dagang, asosiasi etnis, dan lain-lain. Mereka mendorong partisipasi warga negara dan pendidikan kewarganegaraan

Melihat sejarah singkat pasca Perang Dunia II, atas pertanyaan "apa perubahan keseimbangan antara hak dan kewajiban?" Dilanjutkan pada pertanyaan "mengapa politik dan pasar atau hak dan kewajiban harus seimbang?" Sampai pada sebuah jawaban bahwa hak telah banyak berkembang sementara sebagian besar kewajiban warga negara telah memudar menjadi tugas dan tanggungjawab yang tidak jelas atau informal. Sampai pada titik dimana masyarakat jarang mencapai keseimbangan lengkap karena ketidaksetaraan terus-menerus diproduksi oleh pasar sehingga berwujud pada kehidupan sosial yang abstrak.

${ }^{29}$ N. Jaysawal, “Civil Society, Democratic Space, and Social Work,” Journal Stage, October-December 2013, 2013, 1-12, https://doi.org/10. 1177/2158244013504934.

${ }^{30}$ V. Pérez-Díaz, "Civil Society: A Multi-Layered Concept," Current Sociology Review 62, no. 6 (2014): 81230, https://doi.org/10.1177/0011392114533115.

${ }^{31}$ L. Diamond, Developing Democracy toward Consolidation (Yogyakarta: IRE Press, 2003). 
Adanya masyarakat sipil di sini tentunya menjadi harapan untuk menyelesaikan persoalan semacam itu. Masyarakat sipil sebagai gerakan kewargaan mempunyai perjuangan dalam melepaskan cengkraman monopoli politik pasar. Janoski ${ }^{32}$ telah memaparkan bahwa banyak ruang yang dapat dimasuki oleh kelompok masyarakat sipil, baik dalam ranah privat, publik, negara, dan pasar. Tinggal menyesuaikan saja minat kelompok dari setiap masyarakat sipil sesuai dengan visimisi yang akan diperjuangkan. Lingkup kelompok masyarakat sipil ini biasanya berada pada lembaga-lembaga di tingkat makro dan mikro terutama di bidang kenegaraan, organisasi publik, dan kemasyarakatan.

Analisis tentang lahirnya masyarakat sipil dapat ditinjau dari dua sudut pandang. Pertama dari sudut pandang intervensi oleh negara, dengan memanfaatkan penggunaan modal sosial, yaitu melalui strategi penunjukan sebagai fungsi dari pemerintah. Kedua yaitu melalui pendidikan secara berkelanjutan atau pendidikan untuk masa depan. Pendidikan Kewarganegaraan dapat dikatakan sebagai penguat pemahaman warga negara tentang hak dan kewajiban yang dimilikinya. Banyak tokoh menyebutkan hal yang senada, seperti Kerr; dan Ubaedillah. Dengan demikian, PKn dapat dijadikan sebagai instrumen penguat dasar nilai intrinsik hak dan kewajiban warga negara.

Hak dan kewajiban ini sebenarnya memiliki bobot muatan yang sama, yaitu terbagi dalam empat jenis yang meliputi hukum, politik, sosial, dan partisipasi. Jika pemahaman warga negara terhadap hak dan kewajiban seimbang, tentunya cita-cita dalam membentuk masyarakat sipil atau masyarakat madani yang sering digunakan dalam kajian ke-Islaman bukan sekedar wacana publik. Setidaknya Pendidikan Kewarganegaraan sebagai sarana pendidikan yang efektif untuk warga negara mampu membentuk warga negara yang transformatif, yang akan mengambil tindakan untuk mengimplementasikan dan mempromosikan kebijakan, dan perubahan yang konsisten dengan nilainilai seperti hak asasi manusia, keadilan sosial, dan kesetaraan. Singkatnya bertindak sebagai warga negara berarti bertindak atas dasar kepedulian terhadap apa yang diperlukan oleh sesama warga negara.

\section{Kesimpulan dan Saran}

Hak dan kewajiban telah dipetakan secara luas dengan memiliki empat jenis komponen yang sama seperti hukum, politik, sosial, dan partisipatif. Dalam setiap komponen tersebut telah diatur sedemikian rupa pola kerja setiap jenis hak dan kewajiban warga negara. Demi merealisasi keseimbangan antara hak dan kewajiban ini dibutuhkan sebuah Pendidikan sebagai sosialisasi. Melalui Pendidikan Kewarganegaraan, setiap komponen dalam jenis hak dan kewajiban dapat terinternalisasi pada diri setiap warga negara. Sehingga melalui Pendidikan Kewarganegaraan akan melahirkan warga negara yang transformatif, mampu membawa perubahan. Secara kelompok warga negara transformatif akan membentuk sebuah masyarakat yang baik (good society). Dalam bahasa artikel ini yang dimaksud dari masyarakat yang baik adalah masyarakat sipil, karena memiliki tujuan untuk kepentingan publik dan merupakan organisasi atau kelompok yang mampu meningkatkan demokrasi.

\section{Daftar Pustaka}

Banks, J. A. "Failed Citizenship and Transformative Civic Education.” Educational Researcher 46, no. 7 (2017): 366-77. https://doi.org/10.3102/0013189X17726741.

${ }^{32}$ Janoski, Citizenship and Civil Society: A Framework of Right and Obligation in Liberal, Traditional, and Social Democratic Regimes. 
Brandsen, W. T. Trommel, and B. verschuere. "The State and The Reconstruction of Civil Society." International Review of Administrative Sciences 83, no. 4 (2017): 676-93. https://doi.org/10. $1177 / 0020852315592467$.

Budiman, A. State and Civil Society: The Publications Officer, Centre of Southeast Asian Studies. Victoria: Monash University, 1990.

Cohen, J.L., and A. Arato. Civil Society and Political Theory. Cambridge: The MIT Press, 1992.

Diamond, L. Developing Democracy toward Consolidation. Yogyakarta: IRE Press, 2003.

Frimannsson, G. H. "Civic Education and the Good." Studies in Philosophy and Education 20, no. 4 (2001): 303-15. https://doi.org/10. 1023/A:1011834707490.

Giroux, H. A. "Critical Theory and Rationaloty in Citizenship Education." Curriculum Inquiry 10, no. 4 (1980): 329-66.

Gonzales, M. H., E. Riedel, P. G. Avery, and J. L. Sullivan. "Rights and Obligations in Civic Education: A Content Analysis of the National Standards for Civics and Government." Theory \& Reserch in Social Education 29, no. 1 (2001): 109-28. https://doi.org/1080/00933104.2001.10505931.

Hikam, M. A.S. Demokrasi Dan Civil Society. II. Jakarta: LP3ES, 1999.

Janoski, T. Citizenship and Civil Society: A Framework of Right and Obligation in Liberal, Traditional, and Social Democratic Regimes. Cambridge: Cambridge University Press, 1998.

Jaysawal, N. "Civil Society, Democratic Space, and Social Work.” Journal Stage, OctoberDecember 2013, 2013, 1-12. https://doi.org/10. 1177/2158244013504934.

Jover, G. Citizenship Education In and Out of School. In School Curriculum and Civic Education for Building Democratic Citizens by Murray Print and Dirk Lange. Rotterdam: Sense Publishers, 2012.

Karni, A. S. Civil Society \& Ummah. Jakarta: Logos, 1999.

Kerr, D. "Citizenship Education in England: The Making of a New Subject." Online Journal for Social Science Education 2 (2003): 1-10.

Mason, A. "Citizenship and Justice.” Politics, Philosophy \& Economics 10, no. 3 (2011): 263-81. https://doi.org/10.1177/1470594X10386563.

Murdiono, M. Pendidikan Kewarganegaraan Global: Membangun Kompetensi Global Warga Negara Muda. Cetakan Kedua. Yogyakarta: UNY Press, 2018.

Pérez-Díaz, V. "Civil Society: A Multi-Layered Concept." Current Sociology Review 62, no. 6 (2014): 812-30. https://doi.org/10.1177/0011392114533115.

Setiawan, Deny. "Pendidikan Kewarganegaraan Berbasis Karakter Melalui Penerapan Pendekatan Pembelajaran Aktif, Kreatif, Efektif, Dan Menyenangkan.” Jurnal Pendidikan Ilmu-Ilmu Sosial 6, no. 2 (2014): 61-72.

Staeheli, L. A. “Political Geography: Where's Citizenship?” Progress in Human Geography 35, no. 3 (2010): 393-400. https://doi.org/10.1177/0309132510370671.

Sunarso, dkk. Pendidikan Kewarganegaraan: PKN Untuk Perguruan Tinggi. Yogyakarta: UNY Press, 2008.

Tonge, j., A. Mycock, and B. Jeffery. "Does Citizenship Education Make Young People BetterEngaged Citizens?” Political Studies 60, no. 3 (2012): 578-602. https://doi.org/10. 1111/j. 1467-9248.2011.00931.x.

Ubaedillah, A., and A. Rozak. Pendidikan Kewargaan (Civic Education) Demokrasi, Hak Asasi Manusia Dan Masyarakat Madani. Jakarta: ICCE UIN Syarif Hidayatullah, 2008. 
Fikri: Jurnal Kajian Agama, Sosial dan Budaya

Fahdian Rahmandani, Samsuri 